\title{
Cervical Cancer Clinical Primary Tumor TNM Finding v8
}

National Cancer Institute

\section{Source}

National Cancer Institute. Cervical Cancer Clinical Primary Tumor TNM Finding v8. NCI

Thesaurus. Code C139687.

A clinical finding about one or more characteristics of cervical cancer, following the rules

of the TNM AJCC V8 classification system as they pertain to staging of the primary tumor. 